\title{
Importance of copepod carcasses versus faecal pellets in the upper water column of an oligotrophic area
}

\author{
Constantin Frangoulis ${ }^{\mathrm{a}, *}$, Nikolaos Skliris ${ }^{\mathrm{a}, 1}$, Gilles Lepoint ${ }^{\mathrm{a}}$, Khalid Elkalay ${ }^{\mathrm{a}, 2}$, Anne Goffart ${ }^{\mathrm{a}}$, \\ John K. Pinnegar ${ }^{b}$, Jean-Henri Hecq ${ }^{\text {a }}$ \\ a MARE centre, Laboratory of Oceanology, University of Liege, B6, 4000 Liege, Belgium \\ ${ }^{\mathrm{b}}$ Centre for Environment, Fisheries and Aquaculture Science, Lowestoft Fisheries Laboratory, NR33 OHT Lowestoft, UK
}

\section{A R T I C L E I N F O}

\section{Article history:}

Received 27 April 2010

Accepted 12 February 2011

Available online 18 February 2011

\section{Keywords:}

faecal pellets

carcasses

zooplankton

mortality

Mediterranean sea

Oligotrophic area

\begin{abstract}
A B S T R A C T
Downward flux of zooplankton faecal pellets and carcasses was studied during and after the spring bloom in an oligotrophic coastal area of the Western Mediterranean using a 'swimmer-excluding' sediment trap. Zooplankton detritus retrieved in the trap were comprised of cylindrical faecal pellets (from meso- and macrozooplankton) and copepod carcasses with a respective carbon flux of 0.05 $-2.69 \mathrm{mg} \mathrm{m}^{-2} \mathrm{~d}^{-1}$ and $0.42-4.37 \mathrm{mg} \mathrm{m}^{-2} \mathrm{~d}^{-1}$. Carbon and nitrogen flux of carcasses always exceeded that of faecal pellets, except at the beginning of the bloom due to a higher contribution of macrozooplankton faecal material. During the peak of phytoplankton biomass, total faecal flux essentially comprised of copepod faecal pellets (68-86\% of the total faecal carbon), whereas before and after this period, macrozooplankton faecal material dominated (88-91\% of total faecal carbon flux). Copepod faecal flux was positively correlated with phytoplankton biomass. Estimates of non-predatory biomass mortality rates (from $<0.01$ to $0.05 \mathrm{~d}^{-1}$ ) were negatively correlated with chl $a$ with a time lag of 12 days and were lower than predatory mortality values reported in the same area. The paper discusses the relative importance of carcasses versus faecal pellet flux and of non-predatory versus predatory mortality, as well as the potential role of these zooplankton detritus in supporting the production of benthos in oligotrophic areas.
\end{abstract}

(C) 2011 Elsevier Ltd. All rights reserved.

\section{Introduction}

Particulate organic matter downward flux in the ocean is mainly channelled through the sinking of faecal pellets, marine snow and phytoplankton, whereas zooplankton carcasses (i.e. dead animals) are generally considered as being a less important contributor to this downward flux (Turner, 2002). However, as Roman et al. (2002) emphasised, mortality and the resulting carcass flux is an "added source of export that can be important in balancing food-web carbon models; in explaining the discrepancies between estimates of new production and export flux and in linking studies of new and

\footnotetext{
* Corresponding author: Present address: Institute of Oceanography, Hellenic Centre for Marine Research, Former American Base of Gournes, PO Box 2214, 71003 Heraklion, Crete, Greece.

E-mail address: cfrangoulis@her.hcmr.gr (C. Frangoulis).

1 Present address: Dept. of Environmental Physics and Meteorology, Ocean Physics and Modelling Group, University of Athens, University Campus, Bld. Phys-5, 15784 Athens, Greece.

2 Present address: Dept. of Natural Science, Multidisciplinary Faculty of Safi, University of Cadi Ayyad, Route Sidi Bouzid, 4162 Safi, Morocco.
}

total primary production to fisheries". Recent studies concerning carcass flux above $100 \mathrm{~m}$ depth, indicate that it may constitute a large fraction (up to $~ 40 \%$ ) of the total particulate organic carbon flux (Sampei et al., 2009; Frangoulis et al., 2010b).

Both mortality and the carcass flux are difficult to measure in the field. Mortality in general is difficult to estimate in the field as it requires following populations or individual animals over time and the estimation of apparent loss through passive advective processes (Ohman et al., 2004). In addition, most mortality rate measurements (field and lab) concern stage-specific mortality rates of a given species that cannot be easily extrapolated to the whole zooplankton population. Few studies exist concerning values of zooplankton biomass mortality rates (mass of dead organisms over the mass of whole stock, per unit time) although such values are widely used in biogeochemical models (e.g. Frangoulis et al., 2010a).

The passive downward flux of carcasses resulting from the nonpredatory component of mortality (i.e. those associated with starvation, senescence or disease) is also difficult to measure in the field and there are few studies measuring it accurately (review by Buesseler et al., 2007). In fact, despite the fact that zooplankton animals collected in sediment traps often constitute a large part of 
the collected material, especially in shallow traps (within top $200 \mathrm{~m}$ ), carcasses are hard to distinguish from live zooplankton (swimmers) caught accidentally (review by Buesseler et al., 2007).

Among the few accurate measurements of carcass flux, there is almost no direct quantitative comparison with the faecal flux. In the Mediterranean open sea, one model (Andersen and Nival, 1988) and one experimental study (Frangoulis et al., 2010b) found carcass and faecal flux to be of the same order of magnitude. However, the model study, estimating these two fluxes at $200 \mathrm{~m}$ in the NW Mediterranean, lacked field flux data for validation (Andersen and Nival, 1988) whereas the experimental study, using drifting sediment traps deployed at $16 \mathrm{~m}$ depth in the NE Mediterranean, had a short time scale (days), prevented conclusions regarding the relative importance of these two fluxes in general (Frangoulis et al., 2010b).

In oligotrophic coastal areas, considering the high nutrient demand of benthic primary producers, zooplanktonic downward flux (faecal pellets and carcasses) could be an important source of nutrients (particularly $\mathrm{N}$ and $\mathrm{P}$ ) for phytobenthos. In the Mediterranean Sea for example, shallow benthic areas (0-40 m depth) are colonised by very productive benthic primary producers, contributing significantly to the nutrient and carbon fluxes in the system (Lepoint et al., 2004; Barron et al., 2006). The seagrass Posidonia oceanica, the main benthic primary producer in many Mediterranean areas, is known to be effective at trapping suspended particulate matter (Gacia and Duarte, 2001). Enhanced trapping of sestonic particles by seagrass canopies can be an efficient nutrient acquisition in the oligotrophic environments that seagrasses inhabit (Barron et al., 2006). Moreover, bentho-pelagic coupling is significant through the filtering action of its associated epiphytic fauna (Lemmens et al., 1996) and planktonic fish are known to channel pelagic nutrients to the benthic system via faecal pellets and excreta when they rest among the substrate during the night (Pinnegar and Polunin, 2006).

The first aim of the present study was to examine, in the upper water column of an oligotrophic area, during and after the phytoplankton spring bloom, whether the downward flux of zooplankton carcasses is as important as the one of zooplankton faecal pellets.
The second aim was to compare non-predatory versus predatory biomass mortality rate. Finally, using published $\mathrm{N}$ uptake data in the same area (Lepoint et al., 2002, 2004), to estimate if these fluxes could support the production in the Posidonia ecosystem (the main benthic primary producer of the study area).

\section{Material and methods}

In the Bay of Calvi (Fig. 1), chlorophyll a (chl a) and mesozooplankton biomass were analysed from February to mid-April and in early-June 2000. For chl $a$ analysis, every 1-3 days, $1.0 \mathrm{~L}$ of subsurface water $(\sim 2 \mathrm{~m}$ ) taken close to the STARESO station (Fig. 1) was prefiltered through a $200 \mu \mathrm{m}$ mesh screen, then filtered through GF/F filters. Filters were stored at $-20^{\circ} \mathrm{C}$ until pigments were extracted in methanol, and analysed using the method of Williams and Claustre (1991). For mesozooplankton biomass analysis, vertical net hauls were made in the whole water column above the location $\left(8^{\circ} 45^{\prime} \mathrm{E}, 42^{\circ} 35^{\prime} \mathrm{N}\right)$ (Fig. 1) of the sediment trap (described below), every 2-7 days (except in early-April), using a $200 \mu \mathrm{m}$ mesh-size WP2 net. A known fraction, briefly rinsed with distilled water, oven-dried at $60{ }^{\circ} \mathrm{C}(48 \mathrm{~h})$, weighed for dry weight (DW) determination and its $\mathrm{C}, \mathrm{N}$ content analysed using a Carlo-Erba analyser (NA 1500).

For sinking speed measurement of faecal pellets and carcasses, additional vertical net hauls were made to collect animals. To collect faecal pellets, just after the net haul, the captured animals were placed inside a hollow cylinder with a $100 \mu \mathrm{m}$ mesh-size net on the bottom and the cylinder was placed inside a bucket. After $3 \mathrm{~h}$ pellets were concentrated by ladling water from within the bucket using a smaller cylinder with a $20 \mu \mathrm{m}$ mesh-size net at the bottom. Then pellets were collected using a $20 \mu \mathrm{m}$ mesh and preserved at $4{ }^{\circ} \mathrm{C}$ for maximum $24 \mathrm{~h}$. Fresh carcasses were obtained by placing live animals in a freezer $\left(-20{ }^{\circ} \mathrm{C}\right)$ for more than $1 \mathrm{~h}$. The sinking speed of faecal pellets was measured as detailed in Frangoulis et al. (2001). For copepod carcasses, one carcass at a time was released under the water surface of a glass burette filled with $(\mathrm{GF} / \mathrm{F})$ filtered seawater. Carcasses and intact pellets were counted and measured (length and width). Estimates

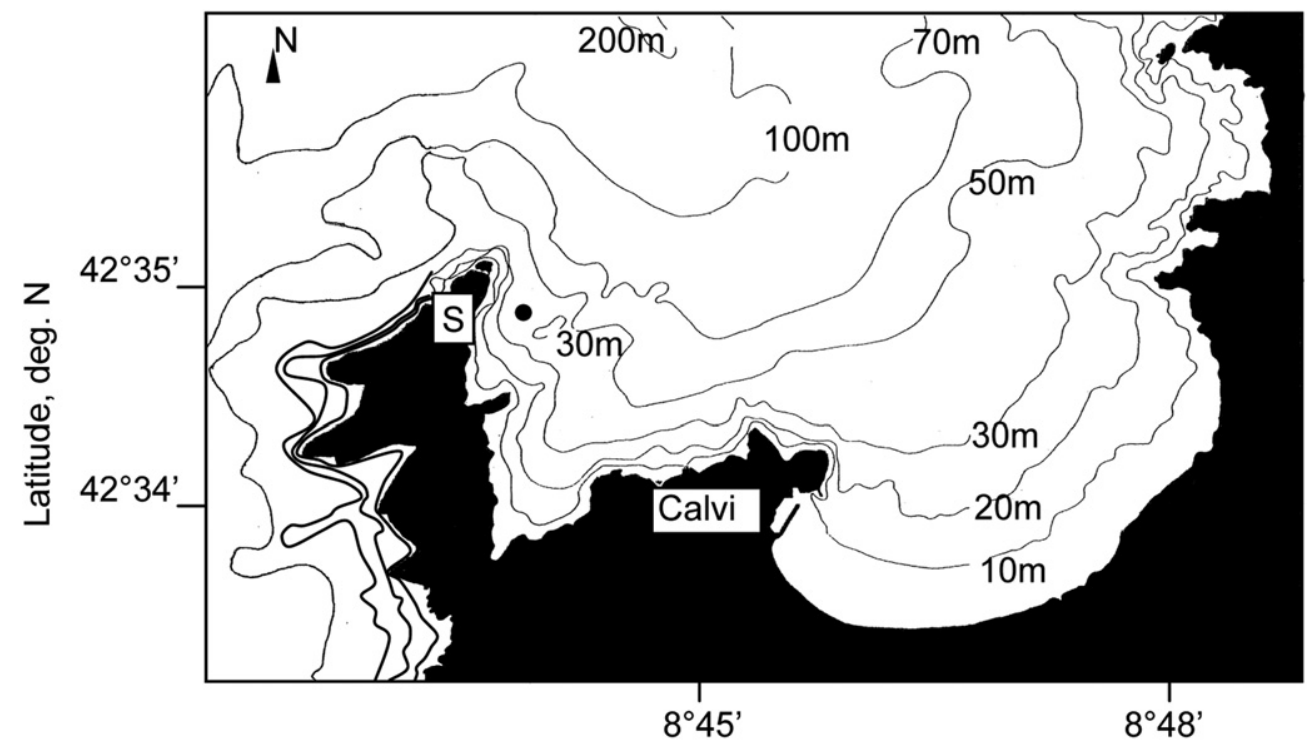

Longitude, deg. $\mathrm{N}$

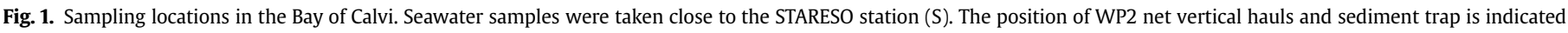
with a black spot. 
of faecal pellet density were obtained, from faecal pellet length, width and sinking speed measurements, based on the relationship of Komar et al. (1981).

A sediment trap was fixed on the sea floor at $\sim 38 \mathrm{~m}$ in the Bay of Calvi (Fig. 1). It was deployed during February, March, and earlyJune 2000 with sampling periods lasting 6 days (except one lasting 17 days). CTD casts were performed every 7-14 days in the water column above the trap. The trap was cylindrical and had an aspect ratio of $\sim 5$ with an inner diameter of $25 \mathrm{~cm}$. The trap entrance was $\sim 2 \mathrm{~m}$ above the sea floor and covered with a net $(\sim 2 \mathrm{~cm}$ meshsize) to avoid the penetration by very large detritus and animals. Samples were collected manually by a scuba diver. To reduce the 'swimmer' effect, the lower part of the trap, included a series of 3 steep glass funnels ending to a collection flask, based on a Coale device (Coale, 1990). The flask was filled with a solution of $\sim 2 \%$ formalin in filtered (GF/F) seawater with a ca 5 salinity increase by addition of $\mathrm{NaCl}$ (Lee et al., 1992). Hydrodynamic biases were considered small since the trap had an aspect ratio $>5$, horizontal advection is generally low in the area (e.g. Skliris et al., 2001) and during the sediment trap deployment period Doppler current profile measurements close to the trap indicated very low current velocities (average $\sim 3 \mathrm{~cm} \mathrm{~s}^{-1}$ ) (Fig. 2).

Trap samples were divided into two fractions. The first one was dried at $60{ }^{\circ} \mathrm{C}$ for $24 \mathrm{~h}$ and weighed to determine the dry weight. Then it was finely ground and the carbon and nitrogen composition was measured using a Carlo-Erba analyser (NA 1500). The second fraction was placed in $4 \%$ formalin. The number of carcasses and faecal pellets in this fraction was counted, and the size (length and width) of carcasses (cephalothorax) and faecal pellets was measured under an inverted microscope. Based on maximum mesozooplankton pellet size values reported in the area (Frangoulis and Hecq, 2010), pellets up to $450 \mu \mathrm{m}$ long were assumed to originate from mesozooplankton and above that from macrozooplankton. Since the sediment trap reduced the swimmer effect (but may not have excluded it completely), the carcasses trapped were also identified based on carcass characteristics (Weikert 1977). Faecal pellet volume was converted to an amount of $C$ or $N$ using mean zooplankton faecal pellet density (estimated as described above), and from Western Mediterranean literature values of pellet DW to wet weight ratio (Elder and Fowler, 1977) and carbon or nitrogen content per pellet DW (Marty et al., 1994). Carcasses size measurements were converted to $\mathrm{C}$ and $\mathrm{N}$, based on Alcaraz et al. (2003).

Non-predatory biomass mortality rate $(M)$ of mesozooplankton was estimated based on the method of Gries and Güde (1999) which calculates the sedimentation losses using the downward flux (VF) of carcasses (measured by the sediment trap) and the mesozooplankton biomass $(\mathrm{AB})$ integrated above the trap and over the time interval $(t)$ of the sediment trap sampling $(M(t)=\mathrm{VF} / \mathrm{AB})$. To compensate for the uneven sampling interval, linear interpolation was used (i.e. the sample interval was used as a weight variable in the average biomass calculation).

The correlations of downward fluxes and mortality rate with phyto- or mesozooplankton biomass above the trap were examined. The data were checked and transformed in order to verify the assumptions of normality and homogeneity. As these assumptions were not respected, the non-parametric Spearman rank correlation coefficient was used.
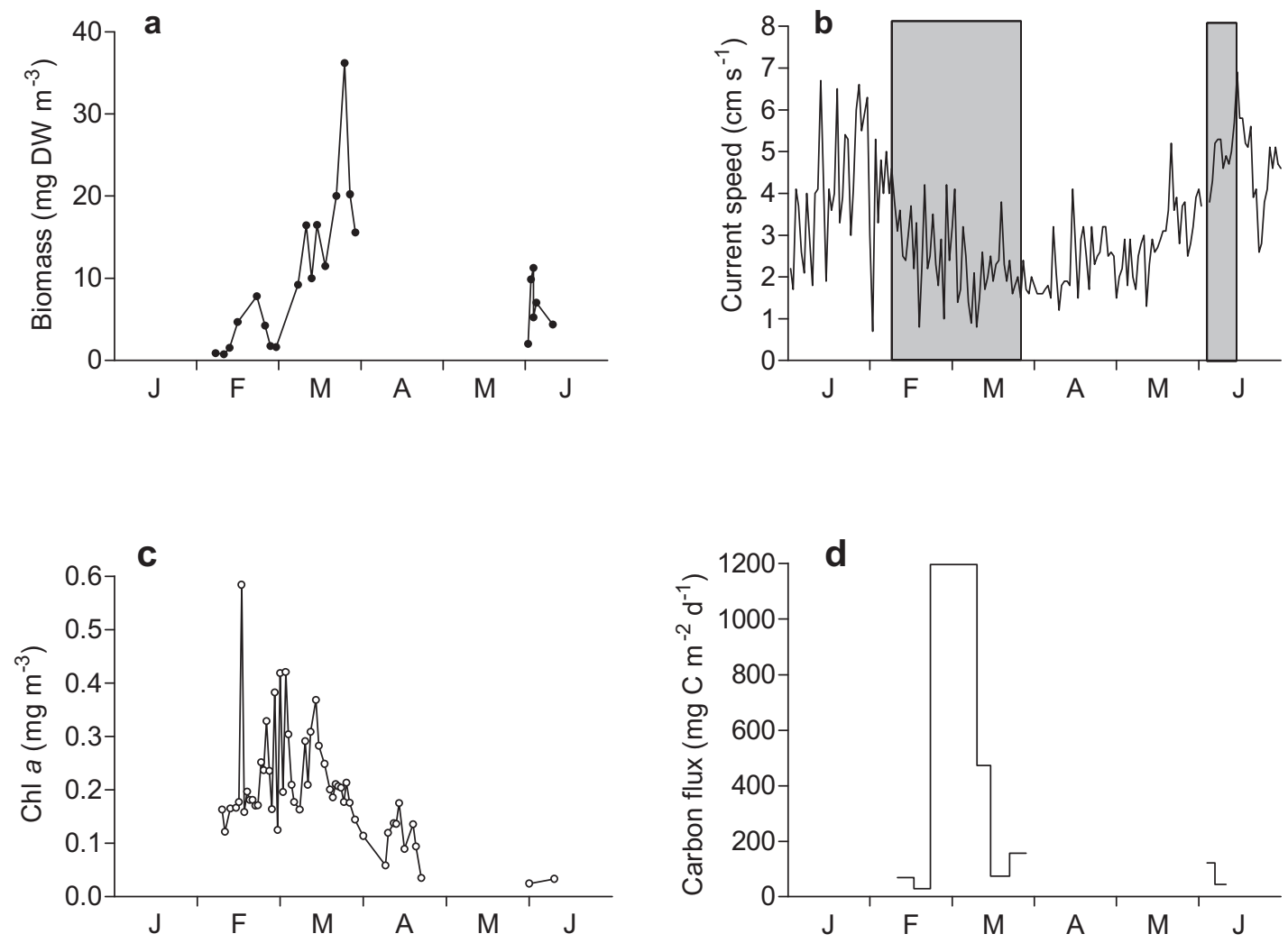

Time (month)

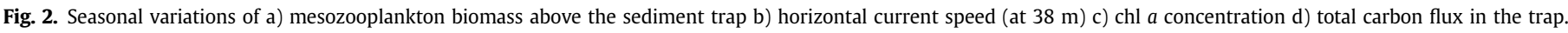
Shadowed areas indicated the periods when the sediment trap was deployed. 


\section{Results and discussion}

\subsection{Copepod carcasses versus faecal pellets downward export}

Concerning carbon export from zooplankton particulate products on a global scale, it is usually faecal pellets, especially those of macrozooplankton, that are considered the most important in terms of downward carbon flux. Zooplankton carcasses are generally considered as being less important in comparison with faecal pellets with regard to the passive downward transport of matter, as most carcasses originating from the upper layer of the water column decompose faster than faecal pellets (review by Frangoulis et al., 2005). Therefore scientific attention has generally focused on zooplankton faecal pellets rather than other zooplankton particulate products.

Mesozooplankton mortality as an export flux from the water column is generally not taken into consideration (Roman et al., 2002), despite the numerous studies on carcasses abundance relative to live copepods (e.g. Tang et al., 2006 and references therein), as well as the high abundances of copepod carcasses observed to accumulate near bottom topographic structures (Genin et al., 1995; Haury et al., 2000) and in traps placed in the upper 200 m layer (Miquel et al., 1994; Gacia et al., 2002; Pantoja et al., 2004). In addition most of these flux studies did not examine the contribution of both carcasses and faecal pellets or did not use swimmer excluding traps in order to distinguish carcasses per se (dead animals) from "swimmers" (e.g. Miquel et al., 1994; Romero et al., 2000).

In the present study, the relative importance of the downward flux of zooplankton faecal pellets versus the one of carcasses during the spring bloom in the oligotrophic Bay of Calvi is examined. During the present study period phytoplankton biomass ( $\mathrm{chl} a$ ) varied from 0.02 to $0.58 \mathrm{mg} \mathrm{m}^{-3}$ and mesozooplankton biomass varied from 0.75 to $36.17 \mathrm{mg} \mathrm{DW} \mathrm{m}^{-3}$ (Fig. 2). The phytoplankton spring bloom is not always strong in this area (i.e. increase may be only up to $0.4 \mu \mathrm{g} \mathrm{L}^{-1}$ chl $a$ ), but is distinguishable as chl $a$ shows higher values (i.e. $>0.2 \mu \mathrm{g} \mathrm{L}^{-1}$ ) in early spring than during the rest of the year (Velimirov and Walenta-Simon, 1992; Goffart et al., 2002).

During the present study, at the depth of $36 \mathrm{~m}$, the total faecal pellet carbon and nitrogen downward flux varied respectively from 0.05 to $2.69 \mathrm{mg} \mathrm{C} \mathrm{m}^{-2} \mathrm{~d}^{-1}$ and from 0.01 to $0.38 \mathrm{mg} \mathrm{N} \mathrm{m}^{-2} \mathrm{~d}^{-1}$ (Fig. 3). All carcasses found in the sediment trap were from copepods and their carbon and nitrogen vertical flux varied respectively from 0.42 to $4.37 \mathrm{mg} \mathrm{C} \mathrm{m}^{-2} \mathrm{~d}^{-1}$ and from 0.08 to $1.07 \mathrm{mg} \mathrm{N} \mathrm{m}^{-2} \mathrm{~d}^{-1}$ (Fig. 3), with minima in mid-February and maxima between end-February and mid-March. As material losses occur due to degradation before pellets and carcasses arrive into the trap, these estimations of downward flux overestimate the amount of $\mathrm{C}$ and $\mathrm{N}$, since they are based on the C and N content of theoretically "fresh" faecal pellets and carcasses (respectively Marty et al., 1994; Alcaraz et al., 2003). These studies (Marty et al., 1994; Alcaraz et al., 2003) were chosen due to their proximity to the present study area; however, they do not exactly represent a fresh faecal pellet and carcass. Alcaraz et al. (2003) collected animals using a net tow and apparently did not remove dead animals before $\mathrm{C}, \mathrm{N}$ analysis, which always constitute an important fraction of such a sample (Elliot and Tang, 2009 and references therein). Similarly, Marty et al. (1994) collected the pellets overnight (maximum $8 \mathrm{~h}$ ) thus some losses before $\mathrm{C}$ measurement had occurred. The measured sinking speed and temperature as well as literature degradation rates were used to evaluate the $C$ losses of faecal pellets and carcasses before arriving in the trap. The measured sinking speed of faecal pellets (14-57 $\mathrm{m} \mathrm{d}^{-1}$, mean $35 \mathrm{~m} \mathrm{~d}^{-1}$ ) and of copepod carcasses (17-324 $\mathrm{m} \mathrm{d}^{-1}$, mean $\left.107 \mathrm{~m} \mathrm{~d}^{-1}\right)$, indicated that a fresh carcass needs $<8$ h to reach the trap and a fresh faecal pellet $<1$ day. The measured mean temperature of the water column (0-36 m) varied from 12.98 to $14.20{ }^{\circ} \mathrm{C}$ during the spring bloom (February-April) and from 17.21 to $18.90{ }^{\circ} \mathrm{C}$ in early-June. Considering the possible overestimation of the C content of "fresh" carcasses and pellets, their sinking speed and the literature $C$ degradation rates for both carcasses and faecal pellets at the closest temperature conditions (equation 1 of Lee and Fisher, 1994 at $18^{\circ} \mathrm{C}$ ), it can be estimated that $>80 \%$ of the initial carcass carbon and $>50 \%$ of the initial faecal carbon reaches the depth of $36 \mathrm{~m}$ during the study period. However, it is important to say that in June, when mean water column temperature increases, higher $C$ losses for carcasses could occur within $8 \mathrm{~h}$ as reported in terms of carcass DW (up to $50 \%$ of carcass DW, Elliot et al., 2010) or proteins (at $20^{\circ} \mathrm{C} 70 \%$, Bickel and Tang, 2010).

The measured carcass carbon flux exceeded, for most of the time, the faecal pellet carbon flux (faecal/carcass flux ratio $<1$ ). A model study in the same region (Andersen and Nival, 1988) estimated that at $200 \mathrm{~m}$ these two fluxes are of the same order of magnitude (i.e. faecal/carcass flux ratio $\sim 1$ ). The conceptual diagram presented in Fig. 4, illustrates the variability of the relative importance of faecal pellets versus carcasses passive (i.e. not due to migration) flux over depth and over time, in a stable water column and assuming faecal pellet and carcasses production is decreasing with depth. In this figure, the results of the present study and these of Andersen and Nival (1988) are presented as examples of the flux at two depths in a simplified (unimodal) way. The increase of the faecal/carcass flux ratio with depth can be explained by the different sinking speeds and degradation times of carcasses and faecal pellets. Although the degradation rate is faster for carcasses than faecal pellets (Lee and Fisher, 1994; Urban-Rich, 1999), the opposite occurs for sinking speed. The present study was carried out at a depth where carcasses, due to their higher sinking speed, can arrive faster than pellets before being notably degraded.

The total faecal pellet numerical downward flux varied from $1.2 \times 10^{3}$ to $49.7 \times 10^{3}$ pellets $\mathrm{m}^{-2} \mathrm{~d}^{-1}$ (Fig. 3). Mesozooplankton faecal pellets constituted the majority of the faecal pellet numerically (75-95\%) and as carbon and nitrogen flux (68-86\%) from mid-February to end-March. By contrast, in early-February and in June (Fig. 3), the dominant faecal pellet numerically (50-60\%) as well as carbon and nitrogen flux (88-91\%) was from macrozooplankton. The absolute values of faecal pellet flux of the present study are close to the ones found in the open Ligurian Sea (Mediterranean Sea) (Miquel et al., 1994, 1995; Carroll et al., 1998). In addition, the present study indicated an increase of faecal flux values from mid-February to end-March, compared to June, and a positive relationship of the numerical downward flux of mesozooplankton faecal pellets with chl $a\left(r^{2}=0.78, P<0.01\right)$, which supports the assumption that the faecal pellet downward flux in this period, corresponds either partially or totally, to the spring 'bloom' of faecal matter downward flux described by other studies in the open Ligurian Sea (January-March in Buat-Ménard et al., 1989; January-April in Fowler et al., 1991; February in Miquel et al., 1994; April-May in Carroll et al., 1998). The main difference between the present study with the open Ligurian Sea is that faecal pellets constitute a much lower percentage of the total carbon flux $(<6 \%)$ than in the open sea $(>20 \%)$ (Miquel et al., 1994, 1995; Carroll et al., 1998). This could be due to two reasons (in addition to the different trap deployment depth). First in the present study, only cylindrical pellets were found (their length varying from 25 to $2940 \mu \mathrm{m}$ ) that could be attributed to copepods and probably euphausiids, whereas in the open Ligurian Sea, cylindrical pellets constituted only part of the faecal flux (e.g. maximum $40 \%$ in Miquel et al., 1994), meaning that other organisms' pellets contributed too to the faecal flux. Secondly, our sediment trap was deployed in a coastal area and the total downward flux of carbon at $36 \mathrm{~m}$ varied 
Faecal pellets
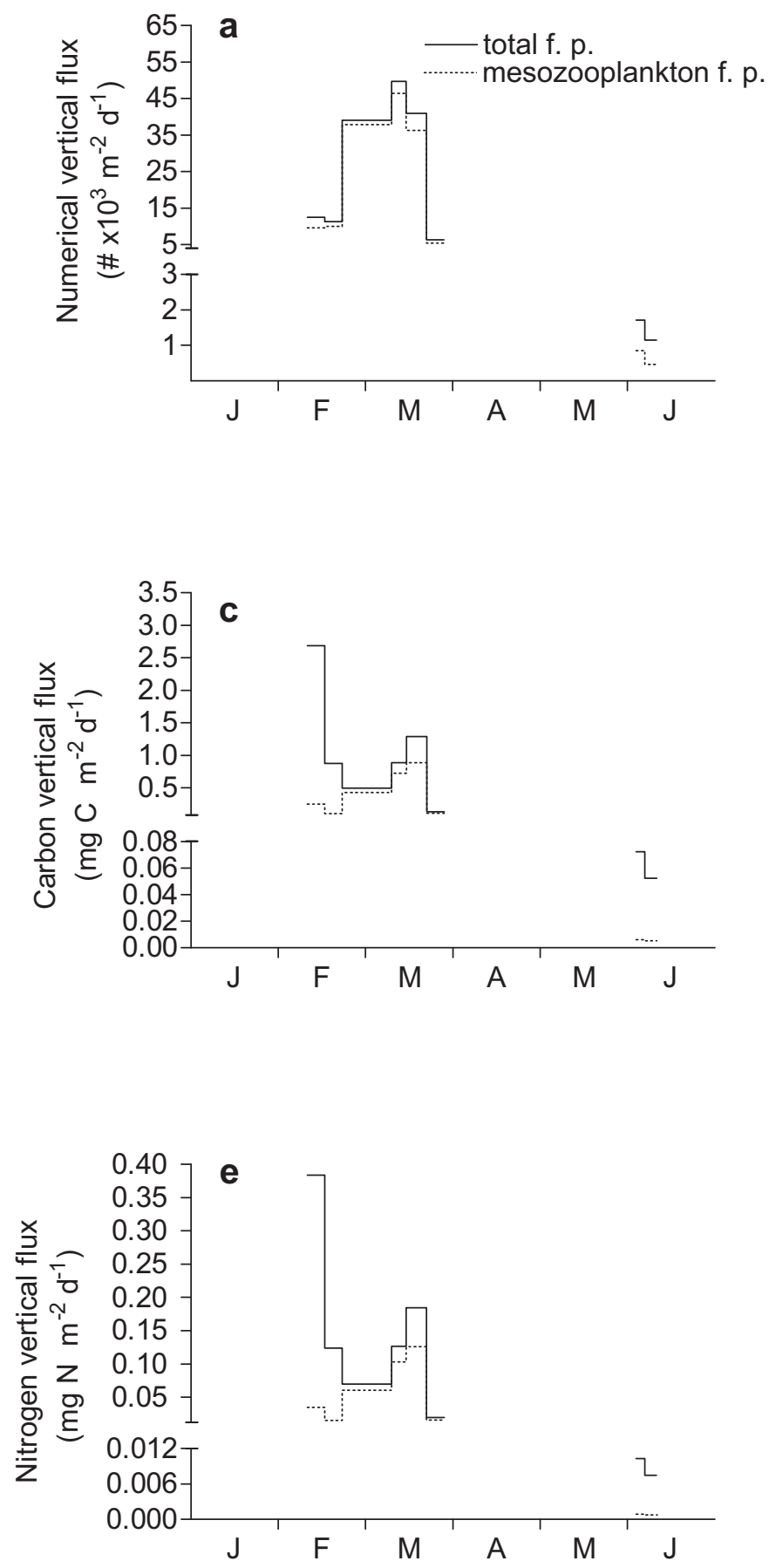

\section{Carcasses}
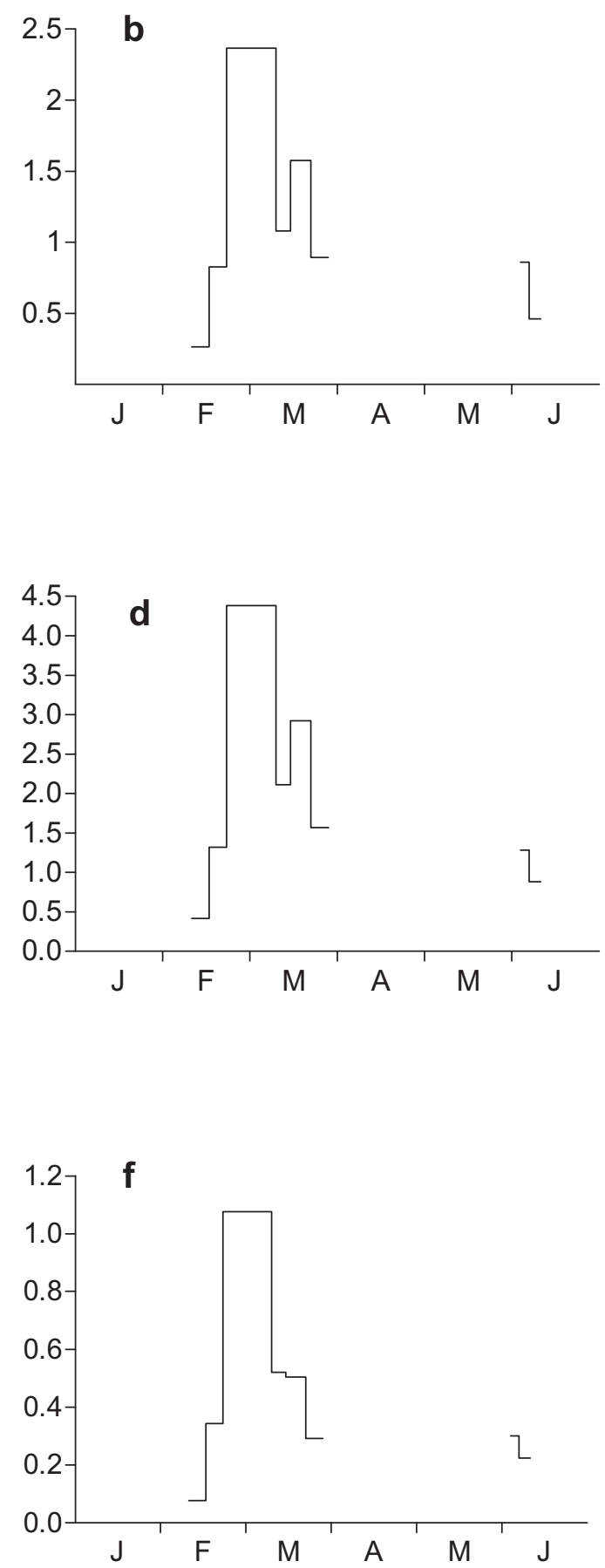

Time (month)

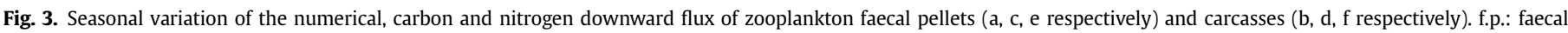
pellet.

between 29 and $1195 \mathrm{mg} \mathrm{C} \mathrm{m}^{-2} \mathrm{~d}^{-1}$ (Fig. 2). In such coastal areas values of total organic carbon (30-5200 $\mathrm{mg} \mathrm{C} \mathrm{m}^{-2} \mathrm{~d}^{-1}$ ) are an order of magnitude higher (e.g. in the same trap location: Dauby et al., 1995; in the north-east Spain: Gacia et al., 2002) than in the open Ligurian Sea (2-50 $\mathrm{mg} \mathrm{C} \mathrm{m}^{-2} \mathrm{~d}^{-1}$ ) (Miquel et al., 1994, 1995; Carroll et al., 1998).

The numerical downward flux of the carcasses varied from 260 to 2360 carcasses $\mathrm{m}^{-2} \mathrm{~d}^{-1}$ (Fig. 3) and was in the same range as at
$15 \mathrm{~m}$ depth in a shallow oligotrophic coastal area of the Western Mediterranean (North-eastern Spain; $\sim 500$ to 2500 carcasses $\mathrm{m}^{-2} \mathrm{~d}^{-1}$; Gacia et al., 2002).

\subsection{Non-predatory and predatory biomass mortality rate}

Mesozooplankton depth-mean non-predatory biomass mortality rate varied between $<0.01$ and $0.05 \mathrm{~d}^{-1}$ (Fig. 5). The range of 


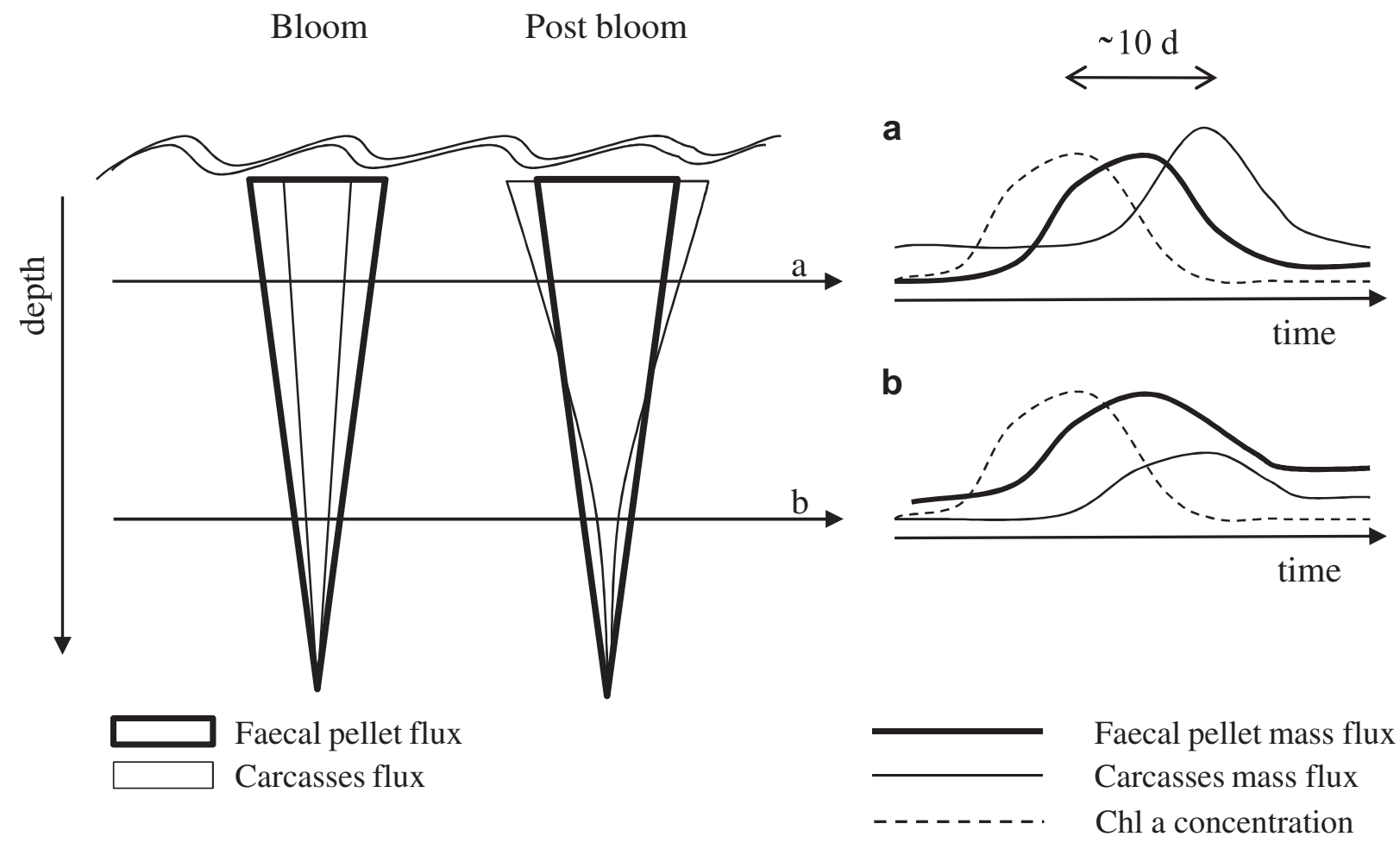

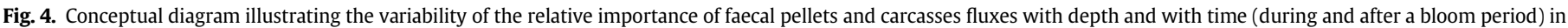

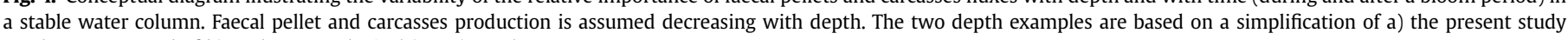
results at $36 \mathrm{~m}$ and of b) Andersen and Nival (1988) results at $200 \mathrm{~m}$.

non-predatory mortality found in the present study is close to the range of literature studies on zooplankton biomass mortality rate (Table 1 ). Most existing mortality rate data are stage-specific mortality rates of given species which may give patterns of what biomass mortality looks like in copepods globally (Hirst and Kiørboe, 2002), but cannot be easily extrapolated to a local zooplankton population.

The present mortality rate range is also very similar to the values used in modelling studies of the Ligurian Sea ecosystem, which vary between 0.02 and $0.05 \mathrm{day}^{-1}$, and are based on model calibration (i.e. not measurements) (Andersen and Nival, 1988; Andersen et al., 1988; Lacroix and Nival, 1998). These model studies expressed mortality rate as depending on food availability (phytoplankton biomass). In the present study, during February and March a significant negative correlation of mortality rate with chl $a\left(r^{2}=0.77, P<0.05\right)$ was found when data were integrated in equal time steps ( 6 days) and a time lag of 12 days was applied. This time lag ( $\sim 10$ days) was reproduced in the model of Andersen and Nival (1998). The relationship of food amount (chl a) with nonpredatory mortality rate supports the need to consider food limitation as a key component of the mortality function in models (review by Carlotti et al., 2000) in order to better reproduce mortality fluxes. The time lag of the relationship mortality-chl $a$ indicates no immediate effect of food limitation to biomass mortality rate. One reason for this lag could be a negative effect of food limitation on copepod egg production and/or on hatching rate, that may cause an increase of non-predatory biomass mortality (Kiørboe and Nielsen, 1994). There are also many other potential reasons for this time lag, because biomass mortality is the output of the interactions within a mixed population (e.g. mortalities of several species, stages and sexes) (reviews by: Ohman and Wood, 1995; Aksnes, 1996; Gries and Güde, 1999).

Predatory mortality in the Bay of Calvi is mainly due to planktivorous fishes which represent $\sim 32 \%$ of the total fish biomass, of which the planktivorous damselfish Chromis chromis makes up the larger part (Pinnegar and Polunin, 2006). In fact, macrozooplankton predators of mesozooplankton (chaetognaths) are scarce or appear sporadically (cnidarians, ctenophores) (Dauby, 1985). C. chromis feeding rates in the same area during the spring bloom period, suggest a consumption of copepods of $42.1 \mathrm{mg} \mathrm{C} \mathrm{fish}{ }^{-1} \mathrm{~d}^{-1}$ or $9.7 \mathrm{mg} \mathrm{N} \mathrm{fish}^{-1} \mathrm{~d}^{-1}$ (Pinnegar et al., 2007). Based on this, the mean predatory mortality rate of mesozooplankton is estimated to be close to $0.2 \mathrm{~d}^{-1}$, using the present depth-integrated spring mean values of mesozooplankton biomass and assuming a density of 1 fish.m ${ }^{-2}$ (Spyker and van den Berghe, 1995) for the Bay of Calvi. Over the coastal rocky littoral predatory mortality rate could be higher as densities of planktonic fish may reach 4.6 ind. $\mathrm{m}^{-2}$ (Pinnegar, 2000). Therefore, zooplankton predatory mortality losses appear to be an order of magnitude higher than non-predatory losses during spring in the Bay of Calvi.

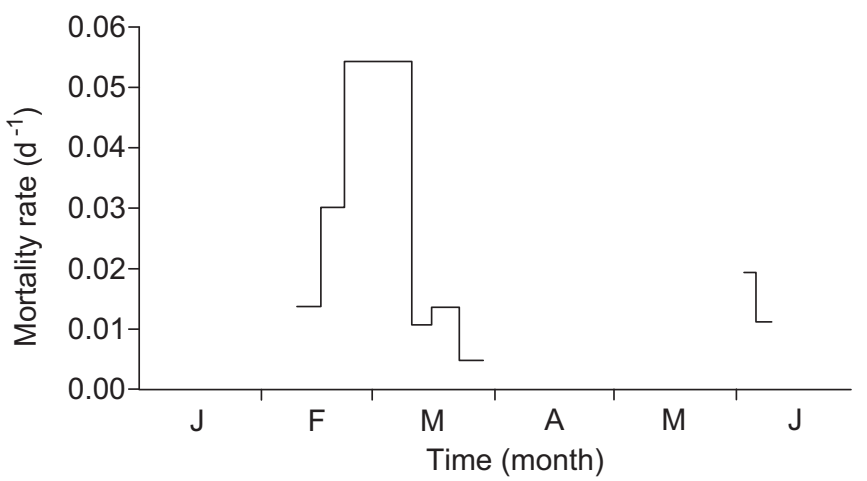

Fig. 5. Seasonal variation of mesozooplankton non-predatory biomass mortality rate in the Bay of Calvi. 
Table 1

Mesozooplankton non-predatory biomass mortality rate studies (methodology and values).

\begin{tabular}{|c|c|c|c|}
\hline Method & Mortality rate $\left(\mathrm{d}^{-1}\right)$ & Area & Reference \\
\hline $\begin{array}{l}\text { Changes of copepod biomass and specific growth rates } \\
\text { over time }\end{array}$ & $0.03-0.15$ & Coastal, Southern Kattegat, Denmark & $\begin{array}{l}\text { Kiørboe and Nielsen, } \\
1994\end{array}$ \\
\hline $\begin{array}{l}\text { Changes of copepod abundance and carcass flux } \\
\text { over time }\end{array}$ & $<0.01-0.12$ & Lake Constance, Germany & Gries and Güde, 1999 \\
\hline Changes of biomass and growth rate over time & $0.06-0.08^{\mathrm{a}}$ & Open ocean, HOT and BATS station & Roman et al., 2002 \\
\hline Time series of size-weight structure analysis & $0.03-0.05$ & Fjord, Sorfjorden, Northern Norway & Edvardsen et al., 2002 \\
\hline $\begin{array}{l}\text { Fraction of dead biomass and carcasses degradation } \\
\text { rate }\end{array}$ & 0.12 & Coastal, Chesapeake Bay, USA & Tang et al., 2006 \\
\hline Changes of biomass and carcass flux over time & $<0.01-0.05$ & Coastal, Bay of Calvi, NW Mediterranean & Present study \\
\hline
\end{tabular}

a Approximate values based on figures 1 and 4 from Roman et al. (2002).

\subsection{Potential importance for benthos}

Zooplankton mortality may also constitute an important nutrient vector linking the pelagic and benthic ecosystems, often more important than faecal pellets. It is estimated above that, at least during the bloom period when temperature reaches the minimum values in our study area, $>80 \%$ of the initial carcass carbon and $>50 \%$ of the initial faecal carbon reaches the depth of $36 \mathrm{~m}$, but afterwards carcasses liberate carbon to the dissolved pool faster than pellets as the former degrade faster. Assuming a similar situation for the nitrogen liberated to the benthos dissolved pool, this nitrogen is thus available for benthic primary producers, especially those living at great depths. At shallow depths $(10 \mathrm{~m})$ the nitrogen $\left(\mathrm{NH}_{4}\right.$ and $\left.\mathrm{NO}_{3}\right)$ uptake flux of Posidonia oceanica leaves (8.9 $\mathrm{mg} \mathrm{N} \mathrm{m}^{-2} \mathrm{~d}^{-1}$; Lepoint et al., 2004) is such that the potential contribution of copepod faecal pellets and carcasses is $<12 \%$ from February to June. However, nitrogen uptake flux by $P$. oceanica at the trap depth $\left(36 \mathrm{~m}\right.$ ) is estimated to be $0.5 \mathrm{mg} \mathrm{N} \mathrm{m}^{-2} \mathrm{~d}^{-1}$ based on measured uptake rates (Lepoint et al., 2002) and biomass (Gobert et al., 2003). In this case the potential contribution from copepod faecal pellets and carcasses could be from $50 \%$ to $>100 \%$ during the bloom period, although this is probably an overestimation, because other benthic primary producers co-exist with $P$. oceanica (e.g. their epiphytes) and may uptake nutrients and, of course, because benthic heterotrophs (bacteria, infauna and epiphytic suspended feeders) may use this material directly. Nevertheless, zooplankton carcasses and faecal pellets undoubtedly contribute to the functioning of benthic ecosystems. As discussed previously, the amount of nitrogen arriving to that depth in the form of carcasses is usually higher than that of pellets and in addition is liberated more rapidly to the dissolved pool. Therefore mesozooplankton carcasses appear to be a more important and rapid contributor to the dissolved pool (except at the early bloom when macrozooplankton pellets have a more important contribution). There is also a second significant indirect nutrient contribution of zooplankton carcasses to the benthos in the area through planktivorous fish faeces consisting primarily of densely packed copepod carcasses (Pinnegar and Polunin, 2006) laid into fish resting shelters during the night, which are usually consumed by benthic scavengers such as shrimps, crabs and small fish. Similarly, zooplankton detritus deposited on the bottom is also a potential food source for detritivorous benthic organisms (Yamaguchi et al., 2002).

\section{Conclusions}

The carcasses $\mathrm{C}$ and $\mathrm{N}$ flux in the upper column can be more important than that of faecal pellets, not only as a $\mathrm{C}$ and $\mathrm{N}$ export but also as an amount of nitrogen liberated to the water column. Here we estimated that $>80 \%$ of carcasses and $>50 \%$ of faecal pellets material reached $36 \mathrm{~m}$ depth during the bloom period, suggesting a significant element of the bentho-pelagic coupling in an oligotrophic coastal area. There are few studies dealing with faecal pellet and carcasses (rate, flux, degradation, sinking etc) simultaneously to allow deriving conclusions in a wider context. However, as in general copepod weight-specific faecal pellet production and non-predatory mortality rates have similar range of values, with carcass sinking speed being higher and degradation lower than the one of faecal pellets (Frangoulis et al., 2005 and references therein), it is likely that the conceptual model (Fig. 4) applies in many other areas. Therefore zooplankton mortality as an export flux from the water column should be taken into consideration together with faecal pellets at least in the upper water column.

The present study also demonstrates the importance of swimmer excluding shallow traps for measurement of carcass fluxes and also for estimation of non-predatory biomass mortality rates. Nonpredatory biomass mortality rate was related to phytoplankton biomass ( $\mathrm{chl} a$ ) indicating the need to consider food limitation into biogeochemical ecosystem model parameterisation.

Further mortality studies are necessary to evaluate the importance of mortality fluxes in biogeochemical cycles in other areas. Such studies are also necessary to explain biomass mortality link with environmental conditions. An hypothesis to examine is whether enclosed areas susceptible to eutrophication (e.g. Southern Kattegat, Lake Constance) reach higher values of mortality rates than open areas (HOT, BATS, Bay of Calvi) (Table 1).

\section{Acknowledgements}

We would like to thank Genevieve Lacroix and Salim Djenidi for providing Doppler current metre data, as well as Renzo Biondo and Alain Dernier for design and construction of the sediment trap. We would like to thank the editor, the anonymous reviewers, Mairi Pantazi, and Josephine Vitali for helpful comments. Operating grant support from FRFC Belgium to CF is gratefully acknowledged. G.L. is Associate Researcher at the F.R.S-FNRS. This paper is the MARE paper number 207.

\section{References}

Aksnes, D.L., 1996. Natural mortality, fecundity and development time in marine planktonic copepods-implications of behaviour. Marine Ecology Progress Series 131, 315-316.

Alcaraz, M., Saiz, E., Calbet, A., Trepat, I., Broglio, E., 2003. Estimating zooplankton biomass through image analysis. Marine Biology 143, 307-315.

Andersen, V., Nival, P. 1988. A pelagic ecosystem model simulating production and sedimentation of biogenic particles: role of salps and copepods. Marine Ecology Progress Series 44, 37-50.

Andersen, V., Nival, P., Harris, R.P., 1988. Modelling of a planktonic ecosystem in an enclosed water column. Journal of the Marine Biological Association of the United Kingdom 67, 407-430.

Barron, C., Middelburg, J.J., Duarte, C.M., 2006. Phytoplankton trapped within seagrass (Posidonia oceanica) sediments are a nitrogen source: an in situ isotope labeling experiment. Limnology and Oceanography 51, 1648-1653.

Bickel, S.L., Tang, K.W., 2010. Microbial decomposition of proteins and lipids in copepod versus rotifer carcasses. Marine Biology 157, 1613-1624. 
Buat-Ménard, P., Davies, J., Remoudaki, E., Miquel, J.C., Bergametti, G., Lambert, C.E., Ezat, U., Quetel, C., La Rosa, J., Fowler, S.W., 1989. Non-steady-state biological removal of atmospheric particles from Mediterranean surface waters. Nature 340, 131-134.

Buesseler, K.O., Antia, A.N., Chen, M., Fowler, S.W., Gardner, W.D., Gustafsson, O., Harada, K., Michaels, A.F., Rutgers van der Loeff, M., Sarin, M., Steinberg, D.K., Trull, T., 2007. An assessment of the use of sediment traps for estimating upper ocean particle fluxes. Journal of Marine Research 65, 345-416.

Carlotti, F., Giske, J., Werner, F., 2000. Modeling Zooplankton dynamics. In: Harris, R.P., Wiebe, P.H., Lenz, J., Skjoldal, H.R., Huntley, M. (Eds.), ICES Zooplankton Methodology Manual. Academic press, London, pp. 571-667.

Carroll, M.L., Miquel, J.C., Fowler, S.W., 1998. Seasonal patterns and depth-specific trends of zooplankton fecal pellet fluxes in the Northwestern Mediterranean Sea. Deep-Sea Research 45, 1303-1318.

Coale, K.H., 1990. Labyrinth of doom: a device to minimize the "swimmer" component in sediment trap collections. Limnology and Oceanography 35, 1376-1381.

Dauby, P., 1985. Le macrozooplancton gélatineux, une source considérable d'enrichissement en matière organique des substrats benthiques infralittoraux. Rapports Commission Internationale pour la Mer Méditerranée 29, 321-322.

Dauby, P., Bale, A.J., Bloomer, N., Canon, C., Ling, R.D., Norro, A., Robertson, J.E., Simon, A., Théate, J.M., Watson, A.J., Frankignoulle, M., 1995. Particle fluxes over a Mediterranean seagrass bed: a one year case study. Marine Ecology Progress Series 126, 233-246.

Edvardsen, A., Zhou, M., Tande, K.S., Zhu, Y., 2002. Zooplankton population dynamics: measuring in situ growth and mortality rates using an Optica Plankton Counter. Marine Ecology Progress Series 227, 205-219.

Elder, D.L., Fowler, S.W., 1977. Polychlorinated Biphenyls: penetration into the deep ocean by zooplankton fecal pellet transport. Science 197, 459-461.

Elliot, D.T., Tang, K.W., 2009. Simple staining method for differentiating live and dead marine zooplankton in field samples. Limnology and Oceanography: Methods 7, 585-594.

Elliot, D.T., Harris, C.K., Tang, K.W., 2010. Dead in the water: the fate of copepod carcasses in the York River estuary, Virginia. Limnology Oceanography 55 1821-1834.

Fowler, S.W., Small, L.F., La Rosa, J., 1991. Seasonal particulate carbon flux in the coastal Northwestern Mediterranean Sea, and the role of zooplankton fecal matter. Oceanologica Acta 14, 77-85.

Frangoulis, C., Hecq, J.H., 2010. Comparison of mesozooplankton faecal pellet characteristics from the Southern North Sea and the Mediterranean Sea during spring bloom conditions. ICES Cooperative Research Report No. 300, pp. 21-23.

Frangoulis, C., Belkhiria, S., Goffart, A., Hecq, J.H., 2001. Dynamics of copepod faecal pellets in relation to a Phaeocystis dominated phytoplankton bloom: characteristics, production and flux. Journal of Plankton Research 23, 75-88.

Frangoulis, C., Christou, E.D., Hecq, J.H., 2005. Comparison of marine copepod outfluxes: nature, rate, fate and role in the carbon, and nitrogen cycles. Advances in Marine Biology 47, 251-307.

Frangoulis, C., Carlotti, F., Eisenhauer, L., Zervoudaki, S., 2010a. Converting copepod vital rates into units appropriate for biogeochemical models. Progress in Oceanography $84,43-51$.

Frangoulis, C., Psarra, S., Zervakis, V., Meador, T., Mara, P., Gogou, A., Zervoudaki, S. Giannakourou, A., Pitta, P., Lagaria, A., Krasakopoulou, E., Siokou-Frangou, I., 2010b. Connecting export fluxes to plankton food web efficiency in the Black Sea waters inflowing into the Mediterranean Sea. Journal of Plankton Research $32,1203-1216$

Gacia, E., Duarte, C.M., 2001. Sediment retention by a Mediterranean Posidonia oceanica meadow: the balance between deposition and resuspension. Estuarine Coastal and Shelf Science 52, 505-514.

Gacia, E., Duarte, C.M., Middelburg. J., 2002. Carbon and nutrient deposition in a Mediterranean seagrass (Posidonia oceanica) meadow. Limnology and Oceanography $47,23-32$.

Genin, A., Gal, G., Haury, L., 1995. Copepod carcasses in the ocean. II. Near coral reefs. Marine Ecology Progress Series 123, 65-71.

Gobert, S., Kyramarios, M., Lepoint, G., Pergent-Martini, C., Bouquegneau, J.M., 2003. Variations à différentes échelles spatiales de l'herbier à Posidonia oceanica (L.) Delile; effets sur les paramètres physico-chimiques du sédiment. Oceanologica Acta 26, 199-207.

Goffart, A., Hecq, J.H., Legendre, L., 2002. Changes in the development of the winterspring phytoplankton bloom in the Bay of Calvi (Northwestern Mediterranean) over the last two decades: a response to the changing climate? Marine Ecology Progress Series 236, 45-60.

Gries, T., Güde, H., 1999. Estimates of the non consumptive mortality of mesozooplankton by measurement of sedimentation losses. Limnology and Oceanography 44, 459-465.

Haury, L., Fey, C., Newland, C., Genin, A., 2000. Zooplankton distribution around four eastern North Pacific seamounts. Progress in Oceanography 45, 69-105.

Hirst, A.G., Kiørboe, T., 2002. Mortality of marine planktonic copepods: global rates and patterns. Marine Ecology Progress Series 230, 195-209.

Kiørboe, T., Nielsen, T.G., 1994. Regulation of zooplankton biomass and production in a temperate, coastal ecosystem 1. Copepods. Limnology and Oceanography 39, 493-507.

Komar, P.D., Morse, A.P., Small, L.F., Fowler, S.W., 1981. An analysis of sinking rates of natural copepod and euphausiid fecal pellets. Limnology and Oceanography 26 , $172-180$
Lacroix, G., Nival, P., 1998. Influence of meteorological variability on primary production dynamics in the Ligurian Sea (NW Mediterranean Sea) with a 1D hydrodynamic/biological model. Journal of Marine Systems 16, 23-50.

Lee, B.G., Fisher, N.S., 1994. Effects of sinking and zooplankton grazing on the release of elements from planktonic debris. Marine Ecology Progress Series 110, 299-307.

Lee, C., Hedges, J.I., Wakeham, S.G., Zhu, N., 1992. Effectiveness of various treatments in retarding microbial activity in sediment trap material and their effects on the collection of swimmers. Limnology and Oceanography 37, 117-130.

Lemmens, J.W.T., Clapin, G., Lavery, P., Cary, J., 1996. Filtering capacity of seagrass meadows and other habitats of Cockburn Sound, Western Australia. Marine Ecology Progress Series 143, 187-200.

Lepoint, G., Gobert, S., Dauby, P., Bouquegneau, J.M., 2004. Uptake of inorganic nitrogen by the benthic and planktonic primary producers of a nutrient-poor coastal area. Journal of Experimental Marine Biology and Ecology 302, 107-122.

Lepoint, G., Millet, S., Dauby, P., Gobert, S., Bouquegneau, J.-M., 2002. An annual nitrogen budget of the seagrass Posidonia oceanica as determined by in situ uptake experiments. Marine Ecology Progress Series 237, 87-96.

Marty, J.C., Nicolas, E., Miquel, J.C., Fowler, S.W., 1994. Particulate fluxes of organic compounds and their relationship to zooplankton faecal pellets in NW Mediterranean Sea. Marine Chemistry 46, 387-405.

Miquel, J.C., Fowler, S.W., La Rosa, J., Buat-Ménard, P., 1994. Dynamics of the downward flux of particles and carbon in the open northwestern Mediterranean Sea. Deep-Sea Research 41, 243-261.

Miquel, J.C., Fowler, S.W., Mostajir, B., La Rosa, J., 1995. Long Term Study of Particulate Carbon Flux in the open NW Mediterranean Sea. In: Global Fluxes of Carbon and Its Related Substances in the Coastal Sea-ocean-atmosphere System (Proceedings of the 1994 Sapporo IBGP Symposium). M\&J International, Yokohama, Japan, pp. 353-359.

Ohman, M.D., Eiane, K., Durbin, E.G., Runge, J.A., Hirche, H.J., 2004. A comparative study of Calanus finmarchicus mortality patterns at five localities in the North Atlantic. ICES Journal of Marine Science 61, 687-697.

Ohman, M.D., Wood, S.N., 1995. The inevitability of mortality. ICES Journal of Marine Science 52, 517-522.

Pantoja, S., Sepulveda, J., González, H.E., 2004. Decomposition of sinking proteinaceous material during fall in the oxygen minimum zone off northern Chile. Deep-Sea Research 51, 55-70.

Pinnegar, J.K., 2000. Planktivorous fishes: links between the Mediterranean littoral and pelagic. PhD Thesis, University of Newcastle, 213p.

Pinnegar, J.K., Polunin, N.V.C., 2006. Planktivorous damselfish support significant nitrogen and phosphorus fluxes to Mediterranean reefs. Marine Biology 148, 1089-1099.

Pinnegar, J.K., Polunin, N.V.C., Videler, J.K., Wiljes, J.J., 2007. Daily carbon, nitrogen and phosphorus budgets for the Mediterranean planktivorous damselfish Chromis chromis. Journal of Experimental Marine Biology and Ecology 352, 378-391.

Roman, M.R., Adolf, H.A., Landry, M.R., Madin, L.P., Steinberg, D.K., Zhang, X., 2002 Estimates of oceanic mesozooplankton production: a comparison using the Bermuda and Hawaii time-series data. Deep-Sea Research 49, 175-192.

Romero, N., Silverberg, N., Roy, S., Lovejoy, C., 2000. Sediment trap observations from the Gulf of St. Lawrence and the continental margin of eastern Canada. Deep-Sea Research 47, 545-583.

Sampei, M., Sasaki, H., Hattori, H., Forest, A., Fortier, L., 2009. Significant contribution of passively sinking copepods to the downward export flux in Arctic waters. Limnology and Oceanography 54, 1894-1900.

Skliris, N., Goffart, A., Hecq, J.H., Djenidi, S., 2001. Shelf-slope exchanges associated with a steep submarine canyon off Calvi (Corsica, NW Mediterranean Sea): a modeling approach. Journal of Geophysical Research 106, 19883-19901.

Spyker, K.A., van den Berghe, E.P., 1995. Diurnal abundance patterns of Mediterranean fishes assessed on fixed transects by scuba divers. Transactions of the American Fisheries Society 124, 216-224.

Tang, K.W., Freund, C.S., Schweitzer, C.L., 2006. Occurrence of copepod carcasses in the lower Chesapeake Bay and their decomposition by ambient microbes. Estuarine Coastal and Shelf Science 68, 499-508.

Turner, J.T., 2002. Zooplankton fecal pellets, marine snow and sinking phytoplankton blooms. Aquatic Microbial Ecology 27, 57-102.

Urban-Rich, J., 1999. Release of dissolved organic carbon from copepod fecal pellets in the Greenland Sea. Journal of Experimental Marine Biology and Ecology 232, $107-124$.

Velimirov, B., Walenta-Simon, M., 1992. Seasonal changes in specific growth rates, production and biomass of a bacterial community in the water column above a Mediterranean seagrass system. Marine Ecology Progress Series 80, 237-248.

Weikert, H., 1977. Copepod carcasses in the upwelling region south of cap blanc, N.W. Africa. Marine Biology 42, 351-355.

Williams, R., Claustre, H., 1991. Photosynthetic pigments as biomarkers of phytoplankton populations and processes in the transformation of particulate organic matter at the Biotrans site $\left(47^{\circ} \mathrm{N}, 20^{\circ} \mathrm{W}\right)$. Deep-Sea Research 38, 347-355.

Yamaguchi, A., Watanabe, Y., Ishida, H., Harimoto, T., Furusawa, K., Suzuki, S. Ishizaka, J., Ikeda, T., Takahashi, M., 2002. Community and trophic structures of pelagic copepods down to greater depths in the western subarctic Pacific (WEST-COSMIC). Deep-Sea Research 49, 1007-1025. 